\title{
Anatomical, phytochemical and histochemical study of Solidago chilensis Meyen
}

\author{
DOUGLAS M.F. DE SOUZA ${ }^{1}$, RAFAELA D. SÁ ${ }^{1}$, EVANI L. ARAÚJO ${ }^{2}$ and KARINA P. RANDAU ${ }^{1}$ \\ ${ }^{1}$ Laboratório de Farmacognosia, Departamento de Ciências Farmacêuticas, Universidade Federal \\ de Pernambuco, Av. Prof. Arthur de Sá, s/n, CDU, 50740-521 Recife, PE, Brazil \\ ${ }^{2}$ Laboratório de Farmacobotânica, Faculdade Pernambucana de Saúde, Rua \\ Jean Emile Favre, 422, Ipsep, 51200-060 Recife, PE, Brazil
}

Manuscript received on May 12, 2016; accepted for publication on August 4, 2016

\begin{abstract}
Solidago chilensis Meyen, belonging to the family Asteraceae, is a plant native to South America and the only representative of the genus in Brazil. This species is popularly known as "arnica" and is used to treat bruises, muscle pain and inflammation. The objective of this work was to contribute to the pharmacognostic standardization of S. chilensis. Cross-sections were obtained, by freehand, for microscopic analysis of root, stem and leaf; for these parts of the plant maceration was also performed according to the method of Jeffrey. For the leaf were still made paradermal sections, scanning electron microscopy analysis, phytochemical and histochemical tests. Thus, it was determined anatomical features useful for diagnosis of the species which, together with identification of the chemical compounds and its histolocalization, provides support to their quality control.
\end{abstract}

Key words: anatomy, arnica, Asteraceae, histochemistry, phytochemistry, Solidago chilensis.

\section{INTRODUCTION}

The family Asteraceae comprises about 25.000 species, reunited in 1.500 genera, of which 2.000 species and 250 genera are found in Brazil (Souza and Lorenzi 2012). They are plants of habit very varied, herbs, subshrubs, climbing or exceptionally trees, and $98 \%$ consists of small plants (Joly 2002).

Among the genera belonging to Asteraceae, stands out Solidago, with about 120 species distributed throughout the world (Weber and Jakobs 2005). The main most studied species are Solidago

Correspondence to: Karina Perrelli Randau

E-mail:krandau@hotmail.com

* Contribution to the centenary of the Brazilian Academy of Sciences. virgaurea L., Solidago gigantea L., Solidago canadensis L. and Solidago chilensis Meyen, this last one native of South America and the only species present in Brazil (Melzig 2004, Russo and Garbarino 2008, Borges and Teles 2015).

Solidago chilensis, popularly known as "arnica", "arnica-brasileira", "arnica-silvestre", "lanceta", among other denominations, is one of 71 plant species of National Relation Medicinal Plants of Interest to Unified Health System (RENISUS) (Brasil 2009). This species is used as a substitute for Arnica montana L. (arnica verdadeira), native to the mountainous regions of Europe, whose flowering capitula are used to treat bruises, muscle pain and inflammation (Horta et al. 2013). Although 
the plant species belonging to different genera, they are called as arnica in function of the similarity of medical use (Lorenzi and Matos 2002).

The popular use of $S$. chilensis is quite old and it is inscribed in the first edition of the Brazilian Pharmacopoeia (Brasil 1926). The leaves of this species have been used in traditional medicine for treatment of pain, inflammation, bruising, swelling and wounds (Di-Stasi et al. 2002, Almeida et al. 2009, Pereira et al. 2012, Santos et al. 2014). The main biological and pharmacological activities reported in the literature are attributed to the presence of flavonoids and diterpenes (SchmedaHirschmann et al. 2002, Valverde et al. 2012).

The search for medicinal plants with therapeutic utility is a very old practice, which currently plays an important role in modern medicine. Despite the increasing use of herbal medicines, few studies have been conducted to ensure their safety and efficacy, and many plants are still used based only on its popular use established (Turolla and Nascimento 2006, Moreira et al. 2014).

Besides safety and efficacy, another important point for the development of an herbal medicine is ensure the quality of the vegetable raw material (Brasil 2014). The microscopic study is, therefore, essential to the standardization of plants used as medicines (Brasil 2010).

Given the above and knowing that $S$. chilensis is indicated in RENISUS for use in Brazil, but that it can be popularly confused with other species, as Arnica montana, it is evident the importance of conducting studies that contribute to the pharmacognostic standardization of Solidago chilensis.

\section{MATERIALS AND METHODS}

PLANT MATERIAL

Several specimens of adult plants of $S$. chilensis were collected in the garden of the Laboratorio de Farmacognosia from the Universidade Federal de Pernambuco, Recife, Pernambuco, Brazil. The voucher specimen was deposited in the Herbarium Dárdano de Andrade Lima, of the Instituto Agronômico de Pernambuco (IPA), under registration number 89308 .

\section{ANATOMICAL CHARACTERIZATION - LIGHT MICROSCOPY}

Various cross-sections at the middle region of the root, stem and leaf fixed in FAA 50 \% (Johansen 1940) were obtained by freehand, using a common razor blade. For leaf were also performed paradermal sections on the adaxial and abaxial faces. Then, all sections were clarified in sodium hypochlorite solution (50\%) (Kraus and Arduin 1997). After washing in distilled water, the cross-sections were stained according to the technique described by Bukatsch (1972), with safranin and astra blue; the paradermal sections were stained with methylene blue (1 \%) (Krauter 1985). Subsequently, semipermanent histological slides were prepared containing cross-sections and paradermal sections of botanical material, following common plant anatomy procedures (Johansen 1940, Sass 1951).

\section{ANATOMICAL CHARACTERIZATION - SCANNING ELECTRON MICROSCOPY (SEM)}

Fresh leaves samples were fixed in $2.5 \%$ glutaraldehyde (buffered with $0.1 \mathrm{M}$ sodium cacodylate) and post fixed in $2 \%$ osmium solution (buffered with $0.1 \mathrm{M}$ sodium cacodylate). After dehydration in ethanol series, the material was submitted to critical point drying (Bal-Tec CPD 030), mounted onto SEM stubs and sputtercoated with gold (Leica EM SCD 500) (Haddad et al. 1998). Both adaxial and abaxial faces were examined with a QUANTA 200 FEG scanning electron microscope in Centro de Tecnologias Estratégicas do Nordeste (CETENE). 


\section{MACERATION}

The maceration was performed according to the method of Jeffrey (Johansen 1940) using fragments of root, stem and leaf that were disintegrated with the mixture of $10 \%$ nitric acid and $10 \%$ chromic acid $(1: 1)$.

\section{PHYTOCHEMISTRY}

The phytochemical profile was performed from $10 \%$ methanolic extracts of leaves of $S$. chilensis obtained by decoction. Silica gel plates were used (Macherey-Nagel) to Thin Layer Chromatography (TLC), employing different eluting systems and appropriate revelators, following a protocol developed in the Laboratório de Farmacognosia of the Departamento de Ciências FarmacêuticasUFPE, supported in studies of Harborne (1998) and Wagner and Bladt (2001), with modifications (Randau et al. 2004). The metabolites surveyed were: flavonoids, cinnamic acid derivatives, coumarins, condensed tannins, hydrolysable tannins, monoterpenes, sesquiterpenes, triterpenes, steroids, sesquiterpene lactones, anthraquinones, iridoids, saponins, alkaloids and reducing sugars.

\section{HISTOCHEMICAL CHARACTERIZATION}

Histochemical tests were made on cross-sections of fresh leaves obtained by the same method used in anatomical characterization. The following specific reagents were used for indicate the presence of substances: potassium dichromate (10\%) for phenolic compounds (Gabe 1968); Liebermann-Burchard reagent for triterpenes and steroids (Harborne 1998); Sudan III for lipophilic substances (Sass 1951); Nadi reagent for essential oils and oleoresins (David and Carde 1964); phloroglucinol for lignin (Johansen 1940); Lugol for starch (Johansen 1940) and hydrochloric acid $(10 \%)$ to establish the nature of the crystals (Jensen 1962). Controls were performed in parallel with the tests and semipermanent histological slides were prepared containing the cross-sections (Johansen 1940, Sass 1951).

\section{ANALYSIS OF HISTOLOGICAL SLIDES}

The analysis of the semipermanent histological slides prepared for anatomical and histochemical characterization and maceration were conducted on images in software (Toup View Image), obtained by digital camera coupled to a light microscope (Alltion).

\section{RESULTS}

\section{ANATOMICAL CHARACTERIZATION}

\section{Root}

In cross-section, the root of $S$. chilensis presents a circular contour (Fig. 1a). It was observed the development of secondary growth with the presence of peridermis, composed of two to three layers of suber (Fig. 1a). The cortical region consists of about ten layers of parenchymatic cells (Fig. 1a) and, in this region, some idioblasts with raphides are visualized (Fig. 1b). The endodermis is uniseriate and has Caspary's strips (Figs. 1a-c). Secretory cavities are found associated with the endodermis (Figs. 1a-c).

The vascular system is formed by xylem, which occupies the entire center of the central cylinder (Fig. 1a), and by phloem, located externally to the xylem (Fig. 1a). However, the phloem is not continuously but arranged in isolated clusters, associated with fibers (Fig. 1a). It is noticed that the secretory cavities that occur in the cortical region are always very close to where is a grouping of phloem and fibers (Figs. 1a-c).

\section{Stem}

The stem, in cross-section, shows circular contour (Fig. 1d), with coating system represented by an incipient peridermis, evidencing the presence of a 
layer of suber (Fig. 1d). The cortical parenchyma, which is an aerenchyma, is well developed (Fig. 1d). The endodermis is uniseriate and presents Caspary's strips (Fig. 1e). Secretory cavities are associated with the endodermis (Fig. 1e).

The collateral vascular bundles are distributed throughout the stem and are arranged forming a ring. Isolated bundles can be found in the cortical region (Fig. 1d). Sclerenchymatic fibers are located near the phloem and, as it was found in the root, the secretory cavities are close to a grouping of phloem and fibers (Fig. 1e). In the parenchymatic medullar region and in the cortical region several idioblasts with raphides are visualized (Fig. 1f).

\section{Leaf}

In frontal view, the leaf of $S$. chilensis is amphistomatic, presenting anisocytic and anomocytic stomata, with a predominance of this latter (Figs. 2a-b). The epidermal cells have walls with sinuous contour and are coated by striated cuticle on both faces (Figs. 2a-b). Furthermore, nonglandular multicellular trichomes are visualized on adaxial and abaxial faces of the leaf (Figs. 2a-b).

Some stomata are situated on the same level of the epidermal cells while others are slightly above of the epidermal cells, details viewed in SEM (Figs. 2c-f). Also in SEM were possible to visualize the non-glandular multicellular trichomes, with enlarged base and acute apex, located on both sides of the leaf (Figs. 2c-e).

In cross-section, the midrib has biconvex contour, with the abaxial region more prominent (Fig. 3a). The epidermis is uniseriate with cells covered by a thick layer of striated cuticle (Figs. 3a-b). Adjacent to the epidermis is the angular collenchyma, composed of two to four strata of cells (Figs. 3a-b).

The collateral vascular bundles are arranged almost in parallel, separated by parenchyma, being one larger and central and the others in the limit region of the midrib with the mesophyll (Fig. 3a). In the parenchyma are idioblasts with raphides (Fig. $3 \mathrm{c})$. Near the xylem and the phloem are displayed sclerenchymatic fibers (Figs. 3a-b), while secretory cavities are found only near the phloem (Figs. 3ad).

The mesophyll is isobilateral, consisting of approximately three strata of palisade parenchyma underlying the both faces of the epidermis and a layer of spongy parenchyma in the central region (Fig. 3e). Small vascular bundles are distributed throughout the mesophyll, surrounded by parenchymatic sheath and with the secretory cavity near the phloem (Fig. 3e).

\section{MACERATION}

In the maceration of the root of $S$. chilensis were visualized parenchymatic cells (Fig. 4a) and vessel elements of the helical type (Fig. 4b). In the maceration of the stem were observed irregular stone cells (Fig. 4c) and, as well as in the root, the presence of vessel elements of the helical type (Figs. 4c-d). In the maceration of the leaf were found non-glandular multicellular trichomes (Fig. 4e) and the vessel elements are the same type as described for the root and stem (Fig. 4f).

\section{PHYTOCHEMICAL PROFILE}

The results of the phytochemical profile of leaves of $S$. chilensis are presented on Table I.

TABLE I

Phytochemical profile of leaves of Solidago chilensis.

\begin{tabular}{lc}
\hline Secondary metabolite class & Result \\
\hline Alkaloids & - \\
Sesquiterpene lactones & + \\
Monoterpenes and sesquiterpenes & + \\
Triterpenes and steroids & + \\
Saponins & + \\
Flavonoids & + \\
Cinnamic acid derivatives & + \\
Coumarins & - \\
Tannins & - \\
Anthraquinones & - \\
Iridoids & - \\
Reducing sugars & + \\
\hline
\end{tabular}

Positive reaction: +; Negative reaction: -. 

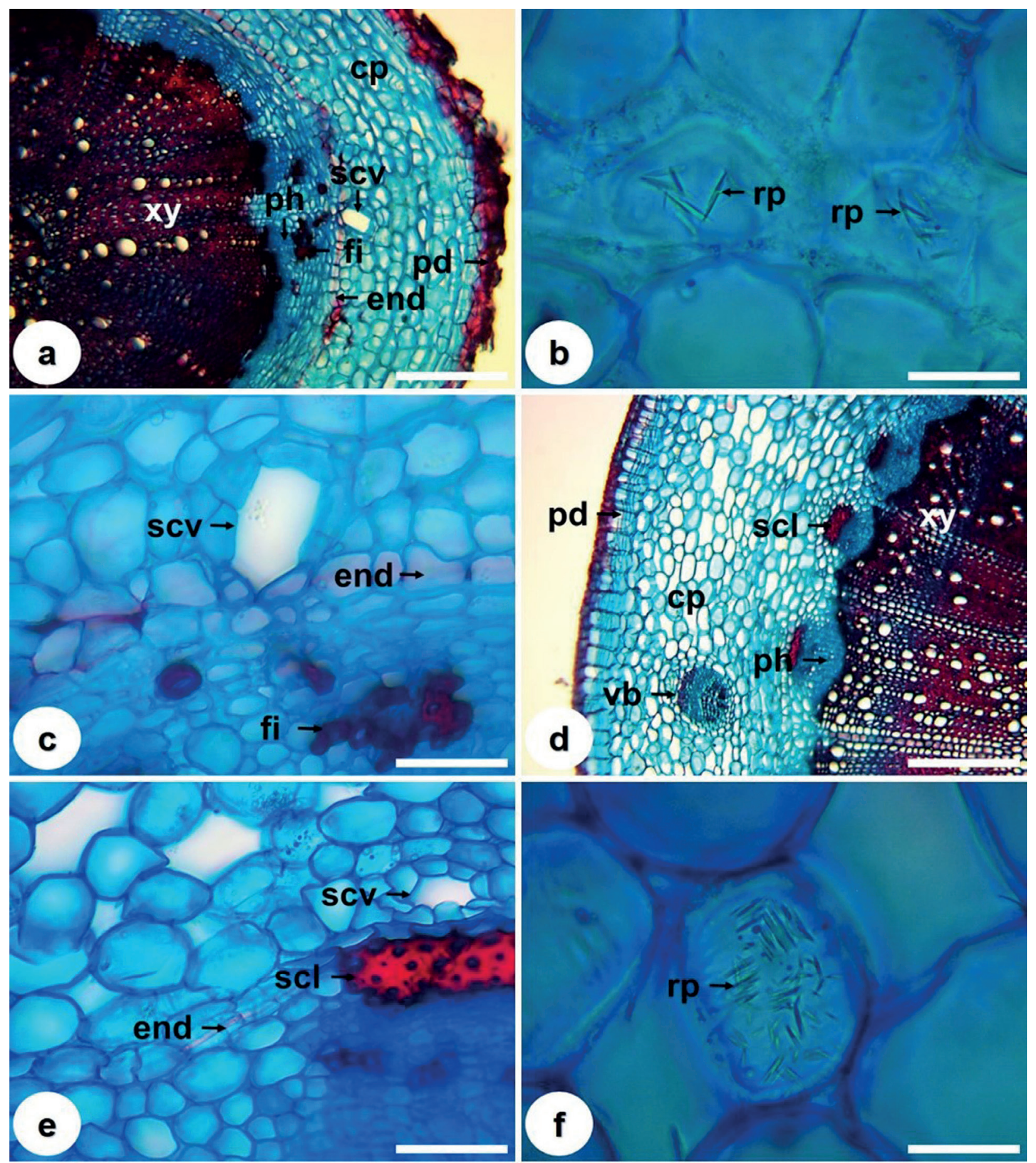

Figure 1 - Solidago chilensis Meyen (Asteraceae) - cross-sections of root and stem. (a) General aspect of the root showing peridermis (pd), cortical parenchyma (cp), secretory cavity (scv), endodermis (end), fibers (fi), phloem (ph) and xylem (xy). (b) Idioblasts with raphides (rp) in cortical region of the root. (c) Detail of the secretory cavity (scv) in cortical region of the root associated with endodermis (end) and fibers (fi). (d) General view of the stem showing peridermis (pd), cortical parenchyma (cp) with isolated vascular bundle (vb), sclerenchyma ( $\mathrm{scl}$ ), phloem (ph) and xylem (xy). (e) Detail of secretory cavity (scv) in cortical region of the stem associated with endodermis (end) and sclerenchyma (scl). (f) Idioblast with raphides (rp) in cortical region of the stem. Bars: $\mathbf{a}, \mathbf{d}=200 \mu \mathrm{m} ; \mathbf{b}$ and $\mathbf{f}=20 \mu \mathrm{m} ; \mathbf{c}$ and $\mathbf{e}=50 \mu \mathrm{m}$. 

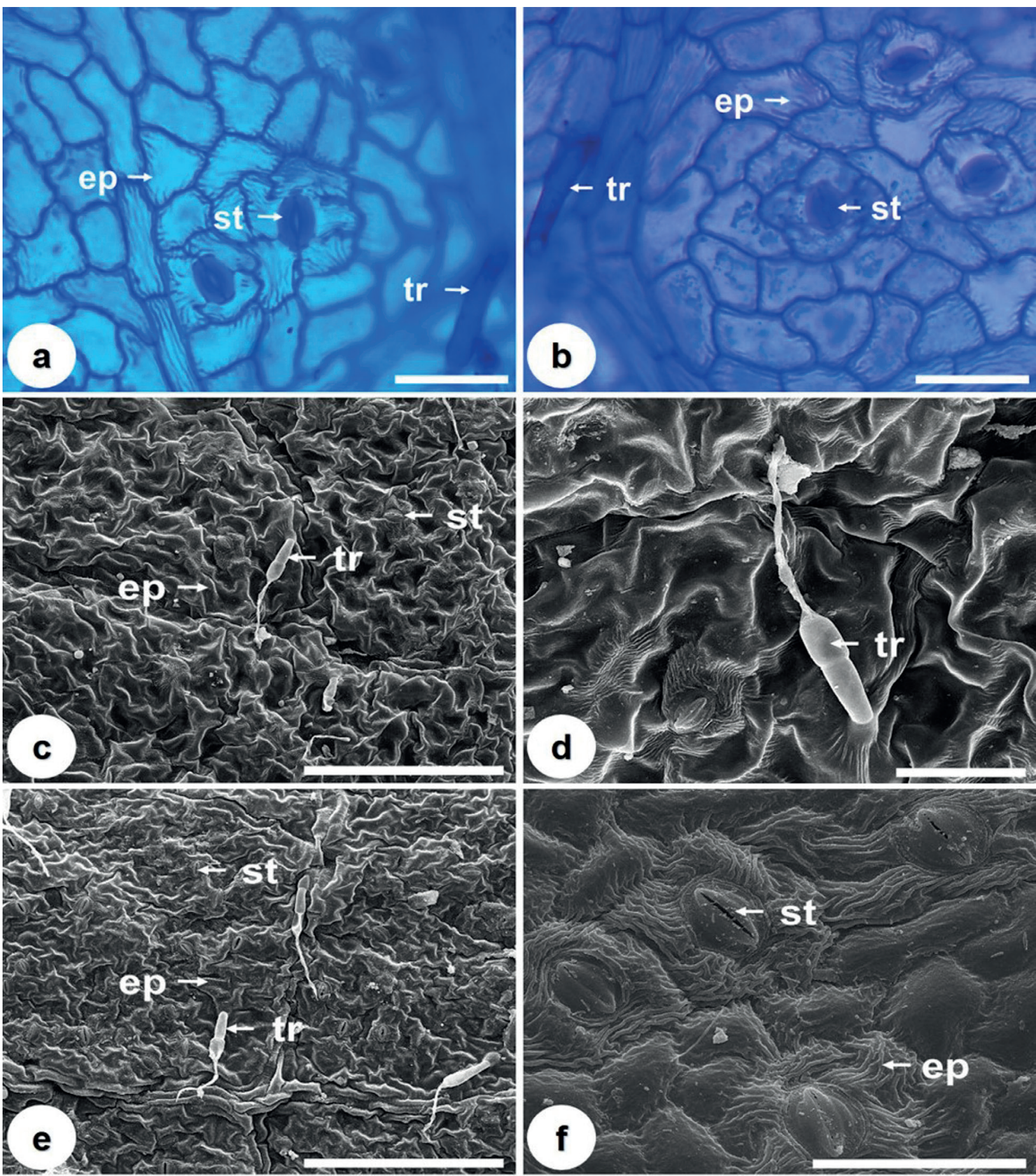

Figure 2 - Solidago chilensis Meyen (Asteraceae), paradermal sections and SEM of the leaf. (a) Adaxial face, showing epidermal cells (ep) coated by striated cuticle, stomata (st) and non-glandular trichome (tr). (b) Abaxial face, where are visualized epidermal cells (ep) coated by striated cuticle, stomata (st) and non-glandular trichome (tr). C-F: SEM of the leaf. (c) View of the adaxial face showing epidermal cells (ep), stomata (st) and non-glandular trichome (tr) (d) Detail of the non-glandular trichome (tr) on adaxial face. (e) View of the abaxial face showing epidermal cells (ep), stomata (st) and non-glandular trichome (tr) (f) Detail of epidermal cells (ep) coated by striated cuticle and stomata (st) on abaxial face. Bars: a, b, $\mathbf{d}$ and $\mathbf{f}=50 \mu \mathrm{m} ; \mathbf{c}$ and $\mathbf{e}=200 \mu \mathrm{m}$. 

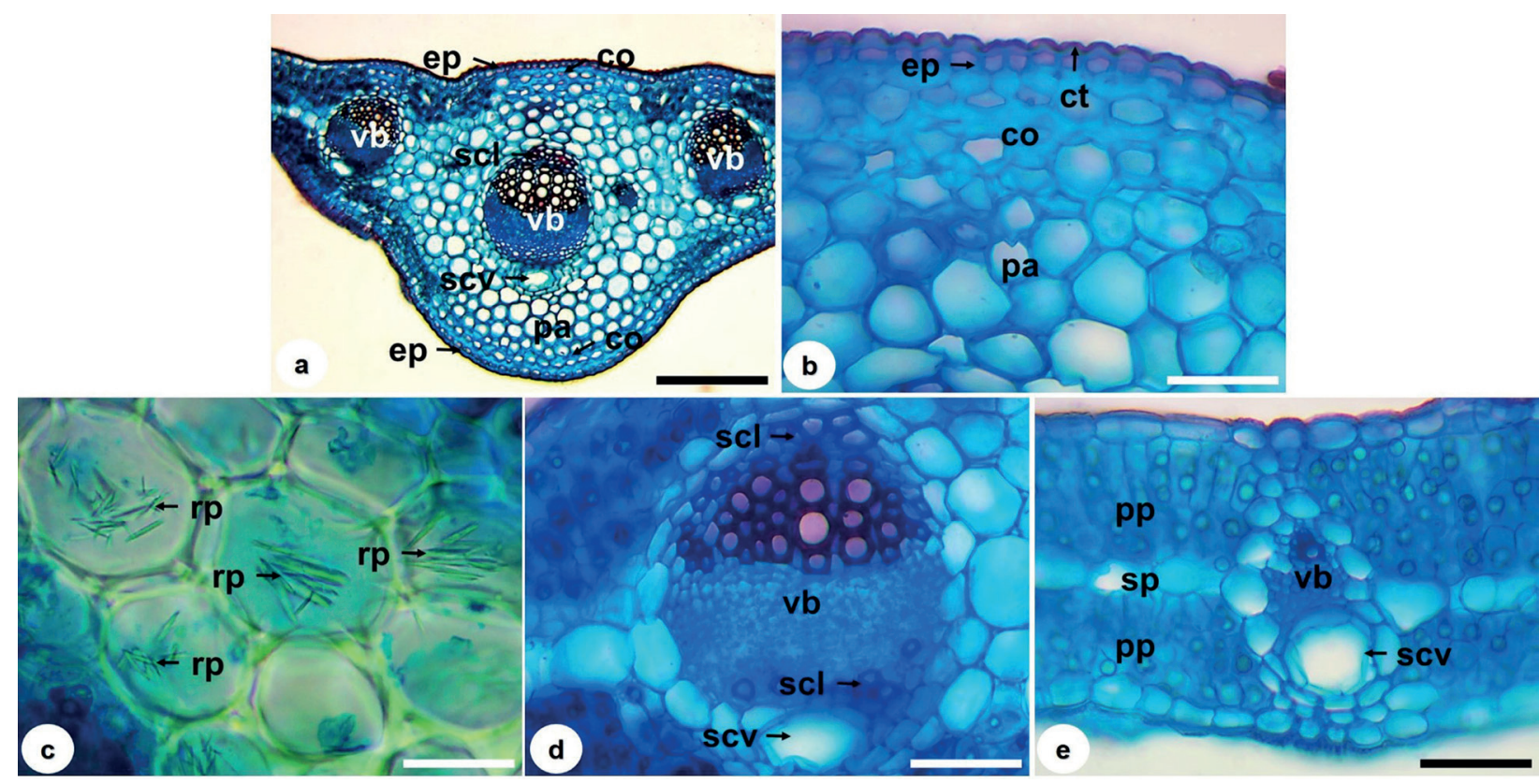

Figure 3 - Solidago chilensis Meyen (Asteraceae), cross-sections of the leaf. (a) View of the midrib, showing epidermis (ep), collenchyma (co), parenchyma (pa), sclerenchyma (scl) and secretory cavity (scv) next to the vascular bundle (vb). (b) Detail of the adaxial region of the midrib, where is observed epidermis (ep) covered by striated cuticle (ct), angular collenchyma (co) and parenchyma (pa). (c) Idioblasts with raphides (rp) in the parenchyma. (d) Detail of sclerenchyma (scl) and secretory cavity (scv) next to the vascular bundle (vb). (e) Detail of palisade parenchyma (pp), spongy parenchyma (sp) and secretory cavity (scv) next to the vascular bundle (vb). Bars: $\mathbf{a}=200 \mu \mathrm{m} ; \mathbf{b}, \mathbf{d}$ and $\mathbf{e}=50 \mu \mathrm{m} ; \mathbf{c}=20 \mu \mathrm{m}$.

\section{HISTOCHEMICAL CHARACTERIZATION}

The figures 5a-b correspond to the cross-sections of the leaf of $S$. chilensis without reagent. When subjected to potassium dichromate, it is observed the presence of phenolic compounds in epidermal cells (Fig. 5c). Besides phenolic compounds, other groups of metabolites demonstrated in the leaf of the species were triterpenes and steroids. By employment of Liebermann-Burchard reagent, it is perceived the presence of these compounds in the palisade parenchyma (Fig. 5d).

The characterization of lipophilic substances with Sudan III is observed by the red color in the cuticle covering the epidermis (Fig. 5e) and in cells surrounding the secretory cavity (Fig. 5f). This acquires a blue color when Nadi reagent was used (Fig. 5g), which indicates the presence of essential oil. The cuticle also shows blue color with the Nadi reagent (Fig. 5g).

The phloroglucinol reagent showed the presence of lignin in the xylem (Fig. 5h). The test to starch was negative. The chemical identification of the crystals as calcium oxalate was confirmed by their dissolution when treated with hydrochloric acid $(10 \%)$.

\section{DISCUSSION}

In the family Asteraceae the presence of secretory cavities associated with the endodermis in the root is a common characteristic, as in some species of the genera Achillea, Gerbera, Scolymus, Scorzonera, Solidago, Stifftia and Tragopogon (Metcalfe and Chalk 1950, Gregio and Mosqueta 2006, Hernández et al. 2013). In the present work was viewed that, in the root, the phloem is associated with fibers. 

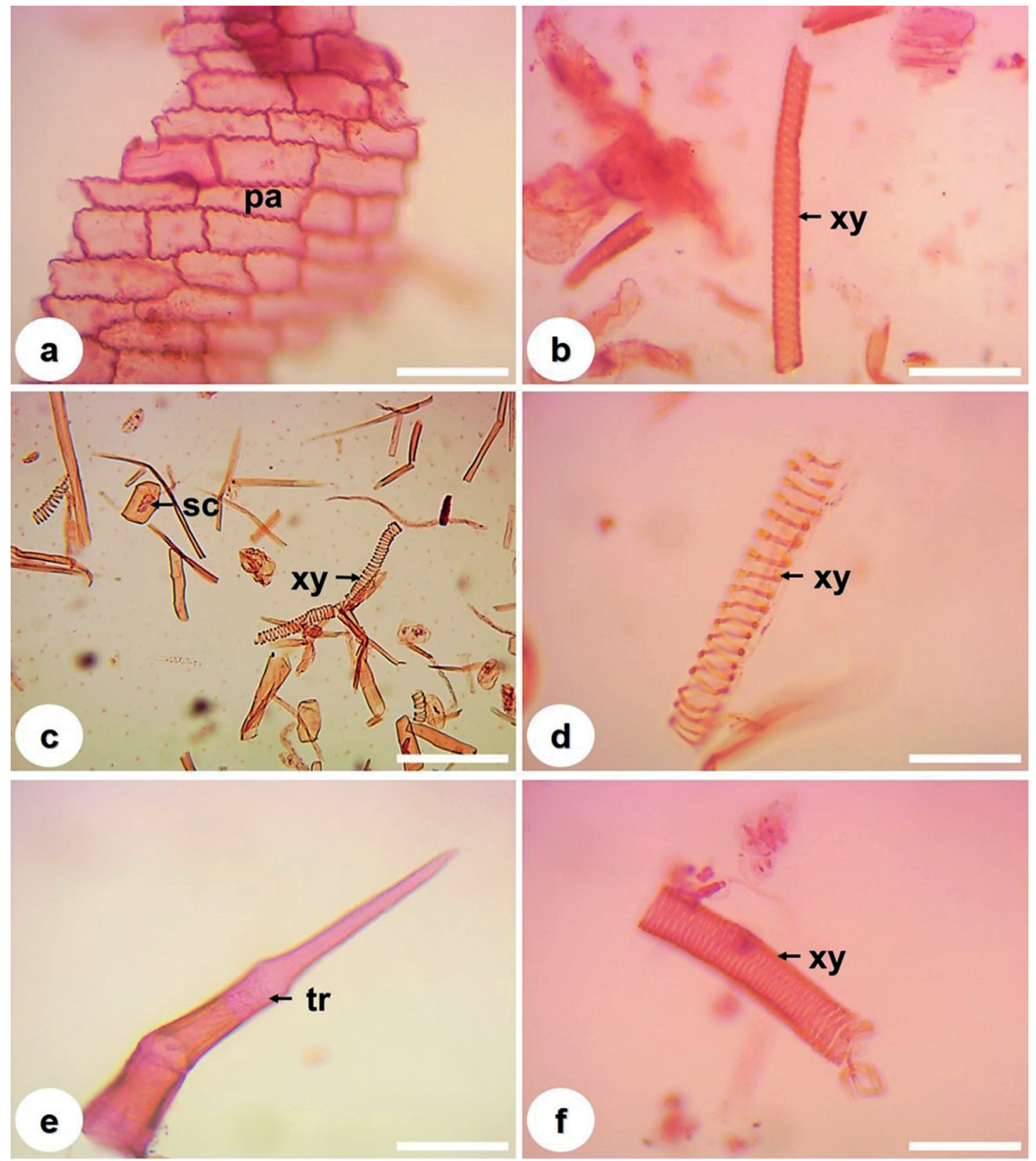

Figure 4 - Solidago chilensis Meyen (Asteraceae), maceration of root, stem and leaf. (a) Maceration of the root, showing parenchymatic cells (pa). (b) Maceration of the root, showing detail of vessel element of xylem (xy) of the helical type. (c) Maceration of the stem, showing stone cells (sc) and vessel elements of xylem (xy). (d) Maceration of the stem, showing detail of vessel element of xylem (xy) of the helical type. (e) Maceration of the leaf, showing non-glandular trichome (tr). (f) Maceration of the leaf, showing detail of vessel element of xylem (xy) of the helical type. Bars: $\mathbf{a}, \mathbf{b}, \mathbf{d}, \mathbf{e}$ and $\mathbf{f}=50 \mu \mathrm{m} ; \mathbf{c}=200 \mu \mathrm{m}$. 


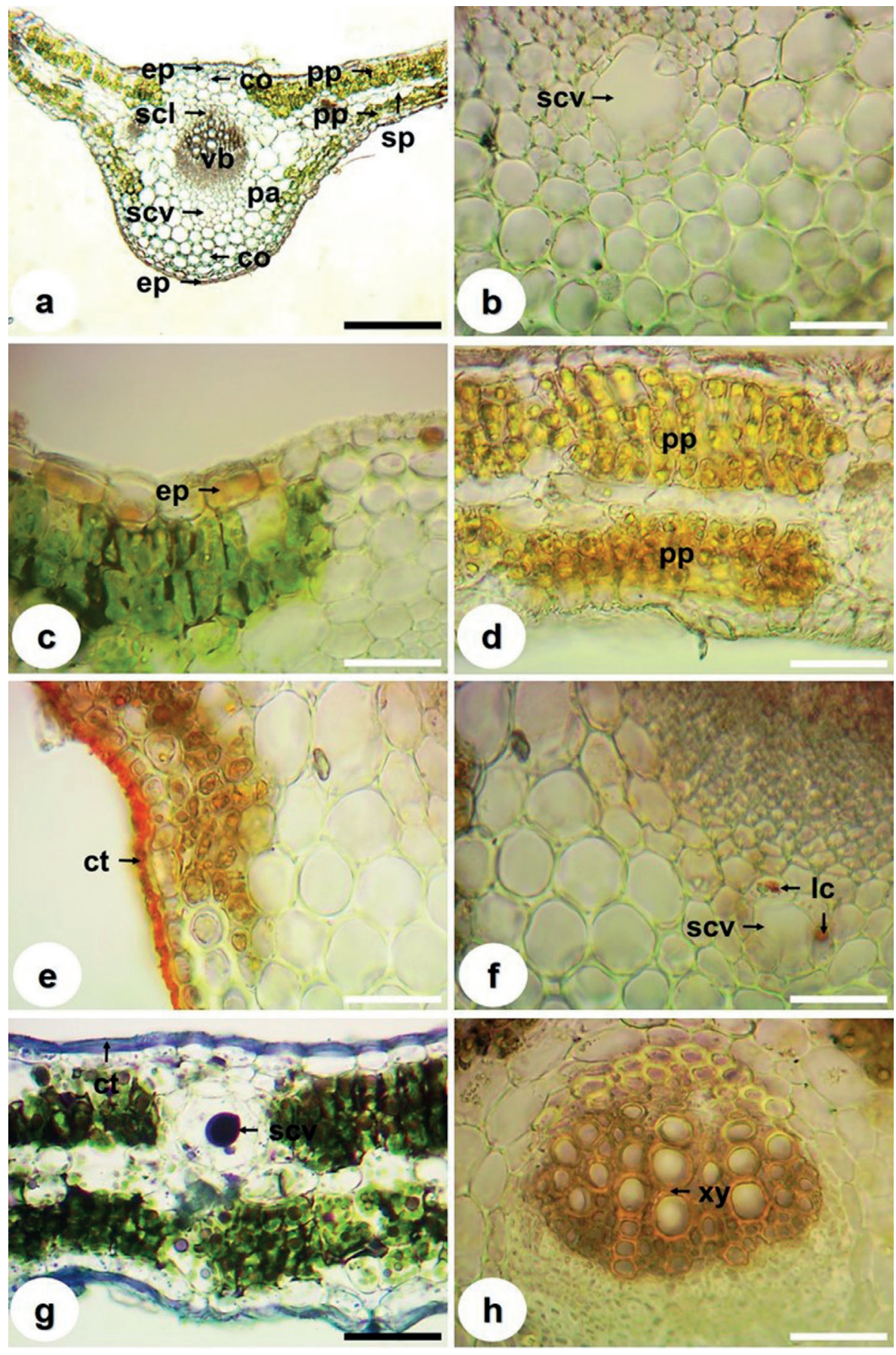

Figure 5 - Solidago chilensis Meyen (Asteraceae), histochemistry of the leaf. (a) Crosssection of the leaf without reagent, showing epidermis (ep), collenchyma (co), parenchyma (pa), sclerenchyma ( $\mathrm{scl}$ ), secretory cavity (scv) next to the vascular bundle (vb), palisade parenchyma (pp) and spongy parenchyma (sp). (b) Detail of secretory cavity (scv) in crosssection without reagent. (c) Phenolic compounds in the epidermis (ep). (d) Triterpenes and steroids in palisade parenchyma (pp). (e) Detail of the cuticle (ct) in midrib evidenced by Sudan III. (f) Lipophilic compounds (lc) in cells that are around the secretory cavity (scv) in midrib. (g) Essential oils inside the secretory cavity (scv) and in the cuticle (ct). (h) Xylem vessels (xy) with lignified walls. Bars: $\mathbf{a}=200 \mu \mathrm{m} ; \mathbf{b}, \mathbf{c}, \mathbf{d}, \mathbf{e}, \mathbf{f}, \mathbf{g}$ and $\mathbf{h}=50 \mu \mathrm{m}$. 
Colares et al. (2014) stated that S. chilensis has no fiber groups on the periphery of the phloem; however, in their study the species not yet presents secondary growth, as was seen in this work.

The presence of aerenchyma in the stem is an important diagnostic character for $S$. chilensis because other species also called "arnica", as Porophyllum ruderale and Chaptalia nutans, exhibit cortical parenchyma with juxtaposed cells (Duarte et al. 2007). Another feature of the stem is the absence of collenchyma in the cortex, which is different from other species of the family that have collenchyma or chlorenchyma (Aguilera et al. 2004, Empinotti and Duarte 2006, 2008, Gregio and Mosqueta 2006, Duarte et al. 2007).

The types of stomata described for the leaf are in agreement with Hernández et al. (2013), but Oliveira et al. (2005) and Roman Junior (2013) mentioned only anomocytic stomata for the species. According to Metcalfe and Chalk (1950), in Asteraceae the stomata are commonly anomocytic and anisocytic.

Besides that, the types of stomata and trichomes can be used as characters for distinguishing the leaves of S. chilensis of the bracts of Arnica montana, which is important since both exhibit green color and are marketed as "arnica". According to Brasil (2010), the plant drug of $A$. montana consists of the dried flowering capitula, in which the bracts are present. Through paradermal sections, it is possible to differentiate them from the leaves of $S$. chilensis because in the bracts are present non-glandular and glandular trichomes and in the leaves of $S$. chilensis it is observed only nonglandular trichomes. Regarding the stomata, the leaves of $S$. chilensis have two types, anisocytic and anomocytic, on both faces. While in the bracts of $A$. montana the stomata are anomocytic and are located only on the abaxial face.

In accordance with Metcalfe and Chalk (1950), the location of the vascular bundles and the secretory cavities in the leaf are characters useful in diagnosis in species of Asteraceae. The species studied, for example, has three well developed vascular bundles in the midrib, as occurs in Siegesbeckia orientalis (Aguilera et al. 2004). Already another species popularly called "arnica", Chaptalia nutans, presents four to six bundles (Empinotti and Duarte 2006), Vernonia condensata has five bundles (Lolis and MilanezeGutierre 2003) and Elephantopus mollis has five to seven vascular bundles (Empinotti and Duarte 2008). With respect to the location of the secretory cavities, in S. chilensis it was observed that they are always near the phloem, as opposed to Siegesbeckia orientalis, where the cavities may be close to the phloem and xylem (Aguilera et al. 2004).

The dorsiventral mesophyll is considered the usual standard for the family, while the presence of crystals is very rare in Asteraceae (Metcalfe and Chalk 1950). However, the presence of crystals in the tribes Astereae, Cardueae, Heliantheae and Inuleae of the family Asteraceae was shown by some recent studies (Meric and Dane 2004, Meric 2008, 2009a, b, Kartal 2016). In the case of the tribe Astereae, which includes $S$. chilensis, several types of calcium oxalate crystals were found, such as styloids, prisms, raphides, druses and crystal sand (Cortadi et al. 1999, Petenatti et al. 2007, Meric 2008, 2009a, Budel and Duarte 2009, 2010, Souza et al. 2013, Jasinski et al. 2014, Budel et al. 2015). Therefore, the type, and presence or absence of crystals may be represented as a taxonomic character (Lersten and Horner 2000, Horner et al. 2012).

The dissociation of tissue reveals some peculiarities of the cells and is a technique recommended by the Brazilian Pharmacopoeia for microscopic analysis of the plant material (Brasil 2010). The phytochemistry was conducted in leaves of $S$. chilensis because this part of the plant is the most used by the population and employed for various medicinal purposes (Santos et al. 2014). Furthermore, the phytochemical study serves as 
support for the histochemical, since it is a more sensitive method for the detection of chemical components of the plant (Wagner and Bladt 2001).

The presence of phenolic compounds, such as flavonoids and cinnamic acid derivative, is consistent with the literature for the species (Chicourel et al. 1998, Gastaldo 2013). In the family Asteraceae the presence of phenolic compounds is well reported (Verdi et al. 2005). In the case of $S$. chilensis, these compounds are mostly described in leaves (Corrêa 1978), where some flavonoids, such as quercetin, quercetrin and rutin, have been isolated and their pharmacological potential was evaluated (Smolarek 2011, Sabir et al. 2012, Roman Junior 2013).

Terpene compounds have been reported in studies with aerial parts of $S$. chilensis by TLC and staining reactions (Smolarek 2011, Gastaldo 2013). Vila et al. (2002) identified the presence of many sesquiterpenes and diterpenes in the essential oil of leaves of $S$. chilensis. The sesquiterpene lactones are considered as chemical markers of Asteraceae and this class of metabolites, together with flavonoids, are considered the active compounds of $S$. chilensis, related to the main medicinal use as anti-inflammatory (Feltrow and Avilla 2000).

Also by staining reactions, Smolarek (2011) characterized anthraquinones and coumarins in hydroalcoholic extracts of the aerial parts of the species and tannins in the aqueous extract of the same plant material. However, Cruz et al. (2013) do not detected positive staining reaction for anthraquinones. In this study, these last three groups of metabolites mentioned were not evidenced, as well as the iridoids. Nevertheless, it must be highlighted the difference in the methodology employed. The detection of coumarins by TLC, as in the present work, was also negative in the leaves of $S$. chilensis in the work of Chicourel et al. (1998). In the case of the tannins, Gastaldo (2013) identified this group of metabolites by TLC, but unlike in the present study, which employed methanolic extracts, the research of the authors was performed with the ethyl acetate fraction of the aerial parts of the plant, which may explain the divergence of the results.

Regarding the presence of saponins, Arambarri and Hernández (2014) detected these compounds in aqueous extracts of root, rhizome, stem, leaf and inflorescence of the plant by froth test. Through the same test, Cruz et al. (2013) and Smolarek (2011) also affirmed the presence of saponins in aqueous extracts of the aerial parts of $S$. chilensis.

Alkaloids were not detected by the method used. Others genera of Asteraceae are known by the presence of alkaloids, such as Ageratum and Senecio (Paiva et al. 2004, Bosi et al. 2013). Reducing sugars were also described in Asteraceae (Ribeiro et al. 2010).

Through histochemical tests was possible to demonstrate the sites of production or accumulation of some metabolites of the plant. For example, the presence of phenolic compounds in epidermal cells may help the plant in different ways, as attractive to pollinators, against pathogens attacks, herbivory, allelopathy and even protection against ultraviolet radiation (Simões et al. 2010). Furthermore, it can be verified that the crystals are of calcium oxalate, which, according to Franceschi and Nakata (2005), are the most common type in plants.

These informations are essential to the differentiation of $S$. chilensis from other species popularly known as arnica and also are important given that the consumption of medicinal plants, although very ample, is not subject to an appropriate quality control and the plant is present in RENISUS. The identification of the chemical compounds of the species and its histolocalization contribute to enlarge the pharmacognostic knowledge about this species.

\section{REFERENCES}

AGUILERA DB, MEIRA RMSA AND FERREIRA FA. 2004. Anatomia e histoquímica dos órgãos vegetativos de 
Siegesbeckia orientalis (Asteraceae). Planta Daninha 22: 483-489.

ALMEIDA NFL, SILVA SRS, SOUZA JM, QUEIROZ APN, MIRANDA GS AND OLIVEIRA HB. 2009. Levantamento etnobotânico de plantas medicinais na cidade de Viçosa, MG. Rev Bras Farmacogn 90: 316-320.

ARAMBARRI AM AND HERNÁNDEZ MP. 2014. Variación estacional de saponinas en Solidago chilensis var. chilensis (Asteraceae). Bol Soc Argent Bot 49: 483-489.

BORGES RAX AND TELES AM. 2015. Solidago. In: Lista de Espécies da Flora do Brasil. Jardim Botânico do Rio de Janeiro. http://floradobrasil.jbrj.gov.br/jabot/floradobrasil/ FB5502. Acesso em 20 de Novembro de 2015.

BOSI CF, ROSA DW, GROUGNET R, LEMONAKIS N, HALABALAKI M, SKALTSOUNIS AL AND BIAVATTI MW. 2013. Pyrrolizidine alkaloids in medicinal tea of Ageratum conyzoides. Rev Bras Farmacogn 23: 425-432.

BRASIL. 1926. Pharmacopeia dos Estados Unidos do Brasil, $1^{\mathrm{a}}$ ed., São Paulo: Nacional, 1149 p.

BRASIL. 2009. Ministério da Saúde. Plantas de interesse ao SUS. http://bvsms.saude.gov.br/bvs/sus/pdf/marco/ms relacao_plantas_medicinais_sus_0603.pdf. Acesso em 20 de Novembro de 2015.

BRASIL. 2010. Farmacopeia Brasileira. 5ª ed., Brasília: Agência Nacional de Vigilância Sanitária, 523 p.

BRASIL. 2014. Ministério da Saúde. Agência Nacional de Vigilância Sanitária. RDC No 26, de 13 de maio de 2014 - Dispõe sobre o registro de medicamentos fitoterápicos e o registro e a notificação de produtos tradicionais fitoterápicos. http://bvsms.saude.gov.br/bvs/saudelegis/ anvisa/2014/rdc0026_13_05_2014.pdf. Acesso em 20 de Novembro de 2015.

BUDEL JM AND DUARTE MR. 2009. Análise morfoanatômica comparativa de duas espécies de carqueja: Baccharis microcephala DC. e B. trimera (Less.) DC., Asteraceae. Braz J Pharm Sci 45: 75-85.

BUDEL JM AND DUARTE MR. 2010. Macro and microscopic characters of the aerial vegetative organs of Carqueja: Baccharis usterii Heering. Braz Arch Biol Technol 53: 123-131.

BUDEL JM, PAULA JP, SANTOS VLP, FRANCO CRC, FARAGO PV AND DUARTE MR. 2015. Pharmacobotanical study of Baccharis pentaptera. Rev Bras Farmacogn 25: 314-319.

BUKATSCH F. 1972. Bemerkungen zur doppelfärbung Astrablau-Safranin. Mikrokosmos 61: 255.

CHICOUREL EL, PIMENTA DS, JORGE LIF AND FERRO VO. 1998. Contribuição ao conhecimento analítico de três compostas medicinais. Rev Bras Farmacogn 7: 59-66.

COLARES MN, HERNÁNDEZ MP, NOVOA MC, PERROTTA VG, AUGUET S AND ARAMBARRI AM. 2014. Anatomía comparada de raíces medicinales de hierbas terrestres rioplatenses (Buenos Aires, República Argentina). Dominguezia 30: 5-17.

CORRÊA MP. 1978. Dicionário das plantas úteis do Brasil e das exóticas cultivadas. Rio de Janeiro: IBDF, 388 p.

CORTADI A, DI SAPIO O, MC CARGO J, SCANDIZZI A, GATTUSO S AND GATTUSO M. 1999. Anatomical studies of Baccharis articulata, Baccharis crispa and Baccharis trimera, Carquejas used in folk medicine. Pharm Biol 37: 357-365.

CRUZ MFG, SOUZA VF, MORAES DCM, RODRIGUES GMC AND PAULA FMSF. 2013. Avaliação da atividade antimicrobiana in vitro da Solidago chilensis e Porophyllum ruderale (arnica brasileira e arnica paulista). Foco 4: 55-70.

DAVID R AND CARDE JP. 1964. Coloration différentielle des inclusions lipidiques et terpéniques des pseudophylles du Pin maritime au moyen du réactif Nadi. C R Acad Sci Paris 258: 1338-1340.

DI-STASI LC, OLIVEIRA GP, CARVALHAES MA, QUEIROZ-JUNIOR M, TIEN OS, KAKINAMI SH AND REIS MS. 2002. Medicinal plants popularly used in the Brazilian Tropical Atlantic Forest. Fitoterapia 73: 69-91.

DUARTE MR, SIEBENROK MCN AND EMPINOTTI CB. 2007. Anatomia comparada de espécies de arnica: Porophyllum ruderale (Jacq.) Cass. e Chaptalia nutans (L.) Pohl. Rev Ciênc Farm Básica Apl 28: 193-201.

EMPINOTTI CB AND DUARTE MR. 2006. Caracteres anatômicos de arnica-do-campo: Chaptalia nutans. Acta Farm Bonaer 25: 333-338.

EMPINOTTI CB AND DUARTE MR. 2008. Estudo anatômico de folha e caule de Elephantopus mollis Kunth (Asteraceae). Rev Bras Farmacogn 18: 108-116.

FELTROW C AND AVILLA J. 2000. Manual de medicina alternativa para o profissional. Rio de Janeiro: GuanabaraKoogan, 744 p.

FRANCESCHI VR AND NAKATA PA. 2005. Calcium oxalate in plants: formation and function. Annu Rev Plant Biol 56: 41-71.

GABE M. 1968. Techniques histologiques. Paris: Masson \& Cie, $1113 \mathrm{p}$.

GASTALDO BC. 2013. Ação de constituintes de Solidago chilensis Meyen (arnica brasileira) nos mecanismos de cicatrização de feridas em ratos. São Paulo. http://www. teses.usp.br/teses/disponiveis/9/9138/tde-19032014151613/pt-br.php. Acesso em 22 de Novembro de 2015.

GREGIO SJD AND MOSQUETA IS. 2006. Anatomia de raiz, caule e folha e identificação de estruturas secretoras de Achillea millefolium L. (Asteraceae). Acta Sci Biol Sci 28: 327-334.

HADDAD A ET AL. 1998. Técnicas básicas de microscopia eletrônica aplicadas às Ciências Biológicas. Rio de Janeiro: Sociedade Brasileira de Microscopia Eletrônica, p. 179. 
HARBORNE JB. 1998. Phytochemical methods. London: Chapman \& Hall, 302 p.

HERNÁNDEZ MP, MARTÍNEZ ALONSO SM, MORANDI LA AND ARAMBARRI AM. 2013. Anatomical and chemical analysis in Solidago chilensis var. chilensis (Asteraceae). Lat Am J Pharm 32: 1236-1240.

HORNER HT, WANKE S AND SAMAIN MS. 2012. A comparison of leaf crystal macropatterns in the two sister genera Piper and Peperomia (Piperaceae). Am J Bot 99: 983-997.

HORTA MP, INSUA LC AND VILLAFRANCA RC. 2013. Usos más frecuentes de Arnica montana. Rev Cubana Plant Med 18: 315-326.

JASINSKI VCG, SILVA RZ, PONTAROLO R, BUDEL JM AND CAMPOS FR. 2014. Morpho-anatomical characteristics of Baccharis glaziovii in support of its pharmacobotany. Rev Bras Farmacogn 24: 506-515.

JENSEN WA. 1962. Botanical histochemistry: principles and practice. San Francisco: W. H. Freeman, 408 p.

JOHANSEN DA. 1940. Plant microtechnique. New York: McGraw-Hill, 523 p.

JOLY AB. 2002. Botânica: introdução à taxonomia vegetal. $13^{\mathrm{a}}$ ed., São Paulo: Nacional, 775 p.

KARTAL C. 2016. Calcium oxalate crystals in some species of the tribe Cardueae (Asteraceae). Bot Sci 94: 107-119.

KRAUS JE AND ARDUIN M. 1997. Manual básico de métodos em morfologia vegetal. Rio de Janeiro: EDUR, $198 \mathrm{p}$.

KRAUTER D. 1985. Erfahrungen mit Etzolds FSA-Färbung für pflanzenschnitte. Mikrokosmos 74: 231-233.

LERSTEN NR AND HORNER HT. 2000. Calcium oxalate crystals types and trends in their distribution patterns in leaves of Prunus (Rosaceae: Prunoideae). Plant Syst Evol 224: 83-96.

LOLIS MIGA AND MILANEZE-GUTIERRE MA. 2003. Morfo-anatomia das folhas de Vernonia condensata Baker (Asteraceae), o "figatil". Rev Bras Farmacogn 13: 68-71.

LORENZI H AND MATOS FJA. 2002. Plantas medicinais no Brasil: nativas e exóticas. Nova Odessa: Instituto Plantarum, $512 \mathrm{p}$.

MELZIG MF. 2004. Goldenrod a classical exponent in the urological phytotherapy. Wien Med Wochenschr 154: 523527.

MERIC C. 2008. Calcium oxalate crystals in Conyza canadensis (L.) Cronq. and Conyza bonariensis (L.) Cronq. (Asteraceae: Astereae). Acta Biol Szeged 52: 295 299.

MERIC C. 2009a. Calcium oxalate crystals in Aster squamatus and Bellis perennis (Asteraceae: Astereae). Phytol Balc 15: 255-259.

MERIC C. 2009b. Calcium oxalate crystals in some species of the tribe Inuleae (Asteraceae). Acta Biol Cracov Ser Bot 51: $105-110$.
MERIC C AND DANE F. 2004. Calcium oxalate crystals in foral organs of Helianthus annuus L. and H. tuberosus L. (Asteraceae). Acta Biol Szeged 48: 19-23.

METCALFE CR AND CHALK L. 1950. Anatomy of the dicotyledons: leaves, stem, and wood in relation to taxonomy with notes on economic uses. Oxford: Clarendon Press, $1500 \mathrm{p}$.

MOREIRA DL, TEIXEIRA SS, MONTEIRO MHD, OLIVEIRA ACAX AND PAUMGARTTEN FJR. 2014. Traditional use and safety of herbal medicines. Rev Bras Farmacogn 24: 248-257.

OLIVEIRA F, AKISUE G AND AKISUE MK. 2005. Farmacognosia. São Paulo: Editora Atheneu, 412 p.

PAIVA JA, BARATA LES AND TRIGO JR. 2004. Pyrrolizidine alkaloids in three Senecio species from southern Brazil. Biochem Syst Ecol 32: 1219-1222.

PEREIRA FL, FERNANDES JM AND LEITE JPV. 2012. Ethnopharmacological survey: a selection strategy to identify medicinal plants for a local phytotherapy program. Braz J Pharm Sci 48: 299-313.

PETENATTI EM, PETENATTI ME, CIFUENTE DA, GIANELLO JC, GIORDANO OS AND TONN CE. 2007. Medicamentos herbarios en el centro-oeste Argentino. VI. Caracterización y control de calidad de dos especies de carquejas: Baccharis sagittalis y B. triangularis (Asteraceae). Lat Am J Pharm 26: 201-208.

RANDAU KP, FLORÊNCIO DC, FERREIRA CP AND XAVIER HS. 2004. Estudo farmacognóstico de Croton rhamnifolius H.B.K. e Croton rhamnifolioides Pax \& Hofffm (Euphorbiaceae). Rev Bras Farmacogn 14: 89-96.

RIBEIRO AO, SILVA AF AND CASTRO AHF. 2010. Identificação de espécies da família Asteraceae, revisão sobre usos e triagem fitoquímica do gênero Eremanthus da Reserva Boqueirão, Ingaí-MG. Rev Bras P1 Med 12: 456-465.

ROMAN JUNIOR WA. 2013. Estudo farmacognóstico para as espécies medicinais Alpinia zerumbet, Solidago chilensis e Eugenia uniflora. Curitiba. http://acervodigital.ufpr. br/bitstream/handle/1884/31918/R\%20-\%20T\%20-\%20 WALTER\%20ANTONIO\%20ROMAN\%20JUNIOR. pdf?sequence=1. Acesso em 22 de Novembro de 2015.

RUSSO A AND GARBARINO J. 2008. Solidago chilensis Meyen e Kageneckia oblonga Ruiz \& Pav.: petite revue de leur profil antioxidant. Phytothérapie 6: 333-341.

SABIR SM, AHMAD SD, HAMID A, KHAN MQ, ATHAYDE ML, SANTOS DB, BOLIGON AA AND ROCHA JBT. 2012. Antioxidant and hepatoprotective activity of ethanolic extract of leaves of Solidago microglossa containing polyphenolic compounds. Food Chem 131: 741-747.

SANTOS MRA, LIMA MR AND OLIVEIRA CLLG. 2014. Medicinal plants used in Rondônia, Western Amazon, Brazil. Rev Bras Pl Med 16: 707-720. 
SASS JE. 1951. Botanical microtechnique. Ames: Iowa State College Press, 391 p.

SCHMEDA-HIRSCHMANN G, RODRIGUEZ J AND ASTUDILLO L. 2002. Gastroprotective activity of the diterpene solidagenone and its derivates on experimentally induced gastric lesions in mice. J Ethnopharmacol 81: 111115.

SIMÕES CMO, SCHENKEL EP, GOSMANN G, MELLO JCP, MENTZ LA AND PETROVICK PR. 2010. Farmacognosia: da planta ao medicamento. $6^{\mathrm{a}}$ ed., Porto Alegre/Florianópolis: Editora da Universidade UFRGS / Editora da UFSC, $1104 \mathrm{p}$.

SMOLAREK FSF. 2011. Contribuição ao estudo fitoquímico, toxicológico e das atividades biológicas da espécie vegetal Solidago microglossa DC (Compositae). Curitiba. http://acervodigital.ufpr.br/ bitstream/handle/1884/37010/R\%20-\%20D\%20-\%20 FERNANDA \%20SANTANA \%20FERREIRA \%20 SMOLAREK.pdf? sequence=3\&isAllowed=y. Acesso em 22 de Novembro de 2015.

SOUZA JP, SANTOS VLP, FRANCO CRC, BORTOLOZO EAFQ, FARAGO PV, MATZENBACHER NI AND BUDEL JM. 2013. Baccharis rufescens Spreng. var. tenuifolia (DC.) Baker: contribution to the pharmacognostic study. Rev Bras Plantas Med 15: 566-574.

SOUZA VC AND LORENZI H. 2012. Botânica sistemática - guia ilustrado para identificação das famílias de fanerógamas nativas e exóticas no Brasil, baseado em APG III. Nova Odessa: Instituto Plantarum.

TUROLLA MSR AND NASCIMENTO ES. 2006. Informações toxicológicas de alguns fitoterápicos utilizados no Brasil. Rev Bras Cienc Farm 42: 289-306.

VALVERDE SS, OLIVEIRA TB AND SOUZA SP. 2012. Solidago chilensis Meyen (Asteraceae). Rev Fitos 7: 131-136.

VERDI LG, BRIGHENTE IMC AND PIZZOLATTI MG. 2005. O gênero Baccharis (Asteraceae): aspectos químicos, econômicos e biológicos. Quím Nova 28: 85-94.

VILA R, MUNDINA M, TOMI F, FURLÁN R, ZACCHINO S, CASANOVA J AND CAÑIGUERAL S. 2002. Composition and antifungal activity of the essencial oil of Solidago chilensis. Planta Med 68: 164-167.

WAGNER H AND BLADT S. 2001. Plant Drug Analysis A thin layer chromatography atlas. $2^{\text {nd }}$ ed., New York: Spinger, $384 \mathrm{p}$.

WEBER E AND JAKOBS G. 2005. Biological flora of central Europe: Solidago gigantean Aiton. Flora 200: 109-118. 